DOI: $10.19195 / 0080-3626.60 .9$

BOGUMIŁA STANIÓW

\title{
KSIĄŻKI Z SERII „BIBLIOTEKA MŁODYCH MICZURINOWCÓW” JAKO PRZYKŁAD ŁĄCZENIA POPULARYZACJI WIEDZY I IDEOLOGIZACJI MŁODEGO POKOLENIA W LATACH 50. XX WIEKU
}

Idee Iwana Miczurina w polskiej szkole lat 50. XX wieku. Sposób popularyzowania wiedzy przez „Bibliotekę Młodych Miczurinowców”, serię Naszej Księgarni, która była wydawana w latach 1953-1956. Idee totalitarnego systemu w książkach BMM jako element wywierania wpływu na światopogląd młodych ludzi.

SŁOWA KLUCZOWE: książka popularnonaukowa dla dzieci i młodzieży, „Biblioteka Młodych Miczurinowców", Polska, 1953-1956

Całe życie spędziłem w sadzie i ogrodzie, dokonując licznych badań i spostrzeżeń w zakresie życia roślin, odkrywając wiele faktów, których strony teoretycznej nauka jeszcze nie dotknęła.

Iwan Miczurin (do młodzieży) ${ }^{1}$

Powszechnie uważa się, że literatura polska okresu stalinowskiego nacechowana była propagandowo i ideologicznie. Dotyczy to również, choć w nieco mniejszym stopniu, książek i czasopism dla dzieci i młodzieży². Jednak dokładna analiza produkcji wydawniczej z tamtego okresu pokazuje, że nie zawsze tak było. Dużo zależało od rodzaju, tematyki książki i jej przeznaczenia, a zwłaszcza czytelnika, do którego była ona kierowana. Oczywiście edycje popularnonaukowe

1 Nasze działki szkolne, Warszawa: Nasza Księgarnia 1956, s. 143.

$2 \mathrm{Na}$ temat opinii i komentarzy dotyczących książki popularnonaukowej w latach powojennych pisałam w artykule pt. Rola książki popularnonaukowej dla dzieci i młodzieży w Polsce w latach 1945-1956: fakty, opinie, komentarze, Roczniki Biblioteczne (54) 2010, s. 97-122. Przykłady oddziałania propagandowego w czasopismach dla dzieci i młodzieży omówiłam w pracy pt. Wielka polityka dla młodych czytelników. „Świat Młodych” w stużbie propagandy w latach 1949-1954, [w:] Bibliologia polityczna. Praca zbiorowa pod red. Dariusza Kuźminy, Warszawa: Wydaw. SBP 2011, s. 337-347. 
stwarzały wydawcy potencjalnie większe pole manewru do ingerencji w treść niż w przypadku literatury pięknej, a popularyzowanie niektórych dyscyplin nauki, takich jak historia, filozofia, socjologia czy religia, możliwe było, tylko gdy prezentowane treści wpisywały się w jedyną słuszną, socjalistyczną doktrynę. Szczególnie widoczna była ingerencja w metateksty, zwłaszcza wstępy, zakończenia czy przypisy. Do wybrania serii „Biblioteki Młodych Miczurinowców” (dalej: BMM) skłoniła mnie, oczywiście, jej nazwa - wskazująca na bezpośrednią ingerencję ideologiczną oraz czas, w jakim była wydawana — schyłek lat stalinowskich.

\section{MICZURIN I MICZURINIZM}

Iwan Miczurin (1855-1935) był rosyjskim biologiem i sadownikiem, który zapoczątkował w biologii teorię i kierunek oparte na wysuniętej przez siebie tezie o dziedziczeniu przez organizmy cech, których nabywają one w drodze krzyżowania gatunków (szczepienia) lub pod wpływem określonych warunków środowiskowych, również jako wynik działalności człowieka. Wyhodował około 300 nowych odmian jabłoni, gruszy i śliw, które odznaczały się m.in. wyższą mrozoodpornością. $\mathrm{Z}$ czasem okazało się, że odmiany te nie nadawały się do reprodukcji, a „sam Miczurin był raczej marzycielem niż wybitnym praktykiem. W drugiej połowie lat 20. XX w. został jednak wykreowany na bohatera ludowego i »ojca jabłek«, a tuż przed śmiercią, w 1935 r., wybrano go na honorowego członka Akademii Nauk ZSSR" ${ }^{3}$. W połowie XX wieku Trofim Łysenko odświeżył teorie Miczurina, budując na nich podstawy socjalistycznego rolnictwa, ,postępowej” radzieckiej biologii, która negowała chromosomową teorię dziedziczności amerykańskiego biologa Thomasa Morgana, za którą ten w 1933 roku otrzymał Nagrodę Nobla. Doktryna dialektyczna Miczurina, zwana przez Łysenkę biologią awangardy, w czasach stalinizmu górowała nad ,idealistyczną, metafizyczną, burżuazyjną teorią dziedziczenia"4. Pokazywała ona, że człowiek może przeobrażać przyrodę, zmieniać cechy roślin dzięki czynnikom zewnętrznym, a przede wszystkim wykształcać te pożądane. Zwiększenie produkcji warzyw i owoców przy użyciu tej metody miało być panaceum na braki żywnościowe, które występowały nawet w najżyźniejszych regionach Związku Radzieckiego, a były konsekwencją komunistycznej kolektywizacji rolnictwa. Łysenkizm szybko przeniknął do szkół i programów nauczania biologii i w ten sposób służył komunistycznej ideologii. Na przyszkolnych działkach zakładano ogródki i hodowle, a gdy nie było odpowiedniego terenu dla takiej działalności - miejscowe państwowe gospodarstwa rolne (tzw. PGR-y) wydzielały szkołom na podstawie umów kawałki ziemi na

3 Anna BIKONT, Sławomir ZAGÓRSKI, Burzliwe dzieje gruszek na wierzbie, http://wyborcza.pl/1,75476,524313.html [dostęp: 5 III 2016].

${ }^{4}$ Ibidem. 
urządzenie ogródków doświadczalnych. Państwowe Zakłady Wydawnictw Szkolnych upowszechniały w Polsce tę ideę nie tylko w książkach skierowanych do pedagogów, lecz także w publikacjach dla dzieci i młodzieży. BMM była serią dla dzieci w wieku szkolnym, która jest dobrym przykładem realizowania powszechnej wówczas idei wychowania nowego człowieka na nowe czasy, przede wszystkim przez włączanie najmłodszych obywateli w realizowanie planów gospodarczych socjalistycznego państwa i wdrażanie idei miczurinizmu.

\section{KSIĄŻKI Z SERII JAKO ŹRÓDŁO INFORMACJI I WIEDZY}

Były to dość typowe dla tego czasu książki popularnonaukowe. Dotyczyły uprawy roślin i hodowli zwierząt prowadzonych w amatorski sposób, pod okiem nauczyciela, w grupie klasowej lub kole zainteresowań, zwanym kółkiem miczurinowskim. Jednak forma, w jakiej przekazywano młodym czytelnikom tę wiedzę, i kontekst historyczny, w którym się one ukazywały, wskazywały na to, jak dużą wagę przywiązywano do tych publikacji. Wydawane były w latach 1953-1956 przez Państwowe Wydawnictwo Literatury Dziecięcej „Nasza Księgarnia" w nakładach 5-20 tys. egzemplarzy (wykaz tytułów znajduje się na końcu tekstu). Większość z nich to miniwykłady popularnonaukowe, z krótkimi elementami narracji oraz prostym, wyjaśniającym, informacyjnym tekstem:

Idziemy dalej. Las staje się coraz suchszy, drzewa są rzadsze, coraz więcej jest słońca. Zatrzymujemy się tu trochę. Tak jest cicho dokoła, życie jednak wre. W pobliżu zabrzęczał jakiś owad, tam odezwał się ptaszek, gdzieś znów spadła sucha gałązka, a tuż, blisko, pracowicie wędruje mrówka dźwigając „ciężką” igłę sosnową.

Czy nie ma gdzieś w pobliżu jakich roślin leczniczych? Rozglądamy się. Oto przed nami ścielą się gęsto rozgałęzione krzewinki borówki brusznicy $[\ldots]^{5}$.

Niektóre, jak np. Szkoła w kwiatach Zofii i Ireny Wilskich czy Od 12 do 312 jaj Lucyny Wiśniewskiej, były napisane w konwencji niemal beletrystycznej, większość raczej w formie popularnonaukowego wykładu, gawędy, która wykorzystywała we fragmentach beletryzację, stosując jeszcze inne formy narracyjne (wiersz ${ }^{6}$, poemat ${ }^{7}$, pamiętnik ${ }^{8}$, list $^{9}$, cytaty ${ }^{10}$, przysło-

5 Józefa BIEGAŃSKA-KORNOWSKA, Leśna apteka, Warszawa: Nasza Księgarnia 1954, s. $7-8$.

${ }^{6}$ Np. wiersz Jana KOCHANOWSKIEGO pt. W petni lata, [w:] Zofia BOHUSZEWICZ, Zbieramy nasiona drzew i krzewów, Warszawa: Nasza Księgarnia 1953, s. 58.

7 Np. opisy lasów z Pana Tadeusza: J. BIEGAŃSKA-KORNOWSKA, op. cit., s. 9.

${ }^{8}$ Np. Zofia i Irena WILSKIE, Szkoła w kwiatach, Warszawa: Nasza Księgarnia 1955, s. 9-10, 49.

9 Ibidem, s. 40 (list od koreańskich kolegów), s. 49 (fragment listu Gorkiego do syna w dzienniczku Władka).

${ }^{10}$ Np. z czasopisma harcerskiego „Świat Młodych”, [w:] Tadeusz PĘCZALSKI, Zakładamy szkolny sad, Warszawa: Nasza Księgarnia 1956, s. 5; z podręczników i poradników, często bez 
wia $^{11}$, hasła ${ }^{12}$ ). Ewenementem w literaturze popularnonaukowej była jedna $\mathrm{z}$ książek tej serii napisana $\mathrm{w}$ formie dramatu ${ }^{13}$. Jedna pozycja była pracą zbiorową, która składała się z barwnych opisów doświadczeń różnych kół miczurinowskich w kraju ${ }^{14}$.

Posługiwały się one typowymi dla książek popularnonaukowych skierowanych do młodych czytelników metodami i technikami oddziaływania na dziecko, np. beletryzacją ${ }^{15}$, dialogizacją, a ich autorzy wykorzystywali różnorodne, dostosowane do wieku dzieci środki stylistyczne i językowe. Zwłaszcza tam, gdzie opowieść popularnonaukowa zmieniała się miejscami w żywy dialog, pojawiały się mini-akcje związane $z$ działaniami dzieci, humorystyczne sceny ${ }^{16}$, a nawet ich przekomarzanie i zabawa. Znacznie częściej stosowane były wówczas rozmaite środki stylistyczne: wykrzykniki, pytajniki, stosowanie pierwszej osoby liczby pojedynczej lub mnogiej itp. W sumie ukazało się 19 książeczek, w tym cztery wznowienia, w dość ubogo wyposażonej broszurowej edycji. Większość zawierała aparat naukowy dostosowany do możliwości percepcyjnych ucznia: tabele, przypisy, a także czarno-białe rysunki, do kilku dołączono kolorowe plansze. Niektóre miały bibliografię tematu („lekturę pomocniczą”), skierowaną raczej do dorosłych czytelników i inne dodatkowe materiały informacyjne ${ }^{17}$. Czasem zawierały słowa wstępne, przypisy, słowniczki terminów, lecz seria nie była ujednolicona w tym względzie.

podania źródła, możliwe że były to przypadki zaaranżowane, tzn. cytowana książka w ogóle nie istniała, np. Lucyna WIŚNIEWSKA, Od 12 do 312 jaj, Warszawa: Nasza Księgarnia 1953, s. 4-5. Zamieszczano cytaty ze starych ludowych zielników (J. BIEGAŃSKA-KORNOWSKA, op. cit., s. 13) i dzieł naukowych, a także innych materiałów, np. cytat Williama WILIAMSA (1863-1939) przed tekstem książki Karla FRIEDELA pt. Gleba w naszym ogródku (Warszawa: Nasza Księgarnia 1955): „Gdy przedmiotem moich zainteresowań stała się gleba, badałem ją we wszelkich jej przeobrażeniach, w czasie i w przestrzeni”" (s. 3). Cytowane były też zapiski z dzienników młodych naukowców, które powstawały na podstawie ich własnych obserwacji.

11 Np. „Ziarnko do ziarnka, a zbierze się miarka”, Z. BOHUSZEWICZ, op. cit., s. 5.

12 Np. „piękne hasło Miczurinowskie: »Jabłko dla każdego dziecka«”, ibidem, s. 11.

13 Jan ŻABIŃSKI, Sami się przekonamy, Warszawa: Nasza Księgarnia 1954.

14 Nasze dziatki...

15 Czasami autor wprowadzał postać fikcyjnych bohaterów, których przeprowadzał po świecie nowych zjawisk i zagadnień, np. w książce Władysława HERMANA pt. Hodowla jedwabników w szkole, Warszawa: Nasza Księgarnia 1955.

${ }^{16} \mathrm{~Np}$. przyłapanie praktykanta z PGR-u na nieformalnej wizycie w ogródku miczurinowskim w książce pt. Nasze działki..., s. 80.

17 Np. w książce J. BIEGAŃSKIEJ-KORNOWSKIEJ pt. Leśna apteka to część pt. Organizacja przemysłu zielarskiego w Polsce (s. 28) i Od Redakcji. Zbieranie roślin leczniczych przez młodzież szkolna (s. 29-31). 


\section{IDEOLOGIZACJA MŁODEGO POKOLENIA W „BIBLIOTECE MŁODYCH MICZURINOWCÓW"}

Niektóre książki serii wprost upowszechniały informacje o darwinizmie i materializmie dialektycznym, np. powołując się na teorię Darwina o zmienności gatunków, powodowanej wpływem różnorodnych warunków życia roślin ${ }^{18}$. Propagowały też idee Miczurina i kółek miczurinowskich ${ }^{19}$, zaznaczając, że powstałe kółka hodowców ${ }^{20}$ roślin nie ograniczają się do standardowych działań, lecz projektują doświadczenia hodowlane (!), zgłębiają teorię miczurinizmu, analizują porażki i osiągnięcia. Patronem tych działań był zawsze Miczurin, zwany przez niektórych mistrzem prac doświadczalnych i czarodziejem. Dlatego był stawiany młodym eksperymentatorom za wzór:

Miczurin umiał patrzeć na roślinę, rozumieć ją i wyprowadzać wnioski ze swych obserwacji. Umiał stwarzać dogodne warunki do rozwoju rośliny i kierować nią, a nade wszystko - umiał pokonywać niepowodzenia i przezwyciężać trudności. Na taką też drogę chcemy cię zaprowadzić. Jeżeliś mazgaj — zawracaj ${ }^{21}$.

Wszystkie działania niedorosłych przyrodników były usankcjonowane pracami radzieckich naukowców, zwłaszcza Miczurina i Łysenki, którzy dowiedli, że „zmiany w roślinie, które zachodzą pod wpływem zmian warunków otoczenia, są dziedziczne, tj. dowiedzione zostało dziedziczenie cech nabytych przez organizm w procesie życia" 22 i teoria ta miała przyświecać w eksperymentalnych działaniach kół. Krąg zainteresowań młodych badaczy wychodził poza skromne rozmiary działki szkolnej i rozciągał się na całą najbliższą okolicę. Namawiano do wyszukiwania informacji na temat tego, które z roślin jadalnych dziko rosnących nadają się do uprawy w ogródku szkolnym, gdyż wcześniej z powodzeniem bywały one pożywieniem człowieka, a ponadto:

Wiele spomiędzy nich zawiera cenne witaminy. [...] Być może, że, dzięki umiejętnej hodowli i selekcji rośliny te mogłyby stać się cennym surowcem dla naszej gospodarki ${ }^{23}$.

Może, stosując metody Miczurina, uda się wyhodować jakaś nową odmianę tej trawy [tj. manny jadalnej] o większych ziarnach, bardziej plenną, odporną na choroby ${ }^{24}$.

$\mathrm{W}$ omawianych tekstach można znaleźć również inne teorie naukowe, zawsze są one autorstwa radzieckich badaczy, a informacje takie przekazywane

18 Wiktor BŁAŻEJEWICZ, Życie chwastów, Warszawa: Nasza Księgarnia 1954, s. 5.

19 Np. w książce Z. i I. WILSKICH, Szkoła w kwiatach.

${ }^{20}$ Znamienne jest, że często w odniesieniu do roślin używano określenia „hodowla”, zamiast „uprawa”, tak jakby doświadczenia przeprowadzane były na żywych, reagujących organizmach.

${ }^{21}$ Nasze dziatki..., s. 9-10.

22 W. BŁAŻEJEWICZ, op. cit., s. 4.

23 Z. BOHUSZEWICZ, Rośliny jadalne dziko rosnace, Warszawa: Nasza Księgarnia 1955, s. 5.

24 Ibidem, s. 19. 
są w specyficzny, pełen patosu sposób, np.: „Z żółtka też powstawały komórki samoistne. Stwierdziła to wielka uczona radziecka Olga Lepieszynska. Dopiero ona udowodniła, że z żółtkowych kulek-ziarnek tworzą się żywe komórki [...]"25. Jednocześnie niektóre z książek serii nie wykazywały niemal żadnego związku z miczurinizmem, np. Jadwigi Wernerowej Na goracym uczynku, która traktuje o tropieniu owadów, ptaków i zwierząt. Tylko w drugiej części książki autorka niepostrzeżenie przechodzi do wizyty w gospodarstwie zajmującym się hodowlą ryb i pokazuje, jak rybacy zagospodarowują dna niewykorzystywanych aktualnie stawów, by w ramach poprawności politycznej skonstatować: „Tak to w planowej gospodarce nic nie powinno leżeć odłogiem, wszystko trzeba odpowiednio zużytkować dla pomnożenia dostatku w kraju"26.

Kilka książek, które ukazały się w serii BMM, propagowało jedność z krajami socjalistycznymi poprzez „owocne kontakty” $\mathrm{z}$ ich młodymi przedstawicielami. Propaganda braterstwa z dziećmi z krajów socjalistycznych dotyczyła przede wszystkim ZSRR i np. „bratniej” Korei. W książce Wilskich cała fabuła oparta jest na kanwie wzajemnych kontaktów polskich uczniów z dziećmi koreańskimi: ich wizyty w polskiej szkole, a potem planowanymi powtórnymi odwiedzinami, do których uczniowie solidnie się przygotowują:

Za chwilę przybędą zaproszeni goście - dzieci koreańskie, które w Polsce znalazły drugą ojczyznę. Wojna wygnała je z ich pięknego kraju. Rodzice i starsze rodzeństwo polegli w walce o wolność. Także wiele z nich choć jeszcze nie dorośli, ofiarnie walczyło z wrogami. Rząd Polski Ludowej zaprosił je do nas, aby przywrócić im dzieciństwo. Otoczone serdeczną przyjaźnią, spokojnie uczą się i pracują. Gdy dorosną, powrócą do Korei, by wziąć udział w odbudowie zniszczonej ojczyzny ${ }^{27}$.

Eksperymenty biologiczne nie wyczerpywały zakresu działań młodzieżowych kół i organizacji. Powinny były one też włączać się aktywnie do realizowania założeń planu sześcioletniego. Ministerstwo Oświaty wydawało w tych sprawach specjalne okólniki i komunikaty, np. o tym jak młodzież szkolna, pod kierunkiem nauczycieli, może wspierać rolnictwo i przemysł, choćby zielarski. Dokumenty te określały, które z ziół można pozyskiwać w ramach uczniowskich prac użytecznych społecznie, jak powinny w te działania się włączać Związek Harcerstwa Polskiego (ZHP) i Związek Młodzieży Polskiej (ZMP) oraz samorządy uczniowskie, jak zastosować w tych akcjach planowość i współzawodnictwo pracy, jak na potrzeby szkół spożytkować należności otrzymane za zebrane zioła ${ }^{28}$ lub inne produkty (mówiło się o „celowym zużytkowaniu” zarobionych w ten sposób pieniędzy). Zebrania drużyn harcerskich przypominały narady partyjne:

\footnotetext{
${ }^{25}$ L. WIŚNIEWSKA, op. cit., s. 8.

26 Jadwiga WERNEROWA, Na goracym uczynku, Warszawa: Nasza Księgarnia 1955, s. 71.

27 Z. i I. WILSKIE, op. cit., s. 6.

28 J. BIEGAŃSKA-KORNOWSKA, op. cit., s. 29-30.
} 
— Druhny i druhowie — rozpoczął przewodnik drużyny — otwieram dyskusję nad celowym zużytkowaniem tych pieniędzy. Zastanówmy się poważnie, na co najlepiej obrócić taką sumę. Zbierając złom przyczyniliśmy się do realizacji planów gospodarczych, musimy pomyśleć nad dalszą pracą. Proszę zabierać głos ${ }^{29}$.

Podobnym celom, spójnym z treścią planu, miały służyć: zadrzewiane lasów, zakładanie ogrodów przyszkolnych przez zbiórkę nasion ${ }^{30}$, zakładanie upraw, sadzenie drzew, stosowanie płodozmianu ${ }^{31}$, pomoc pożytecznym zwierzętom oraz hodowla tych, z których można mieć konkretną korzyść (królików, jedwabników). Niektóre działania wydają się dziś dość oryginalne, np. urządzanie przez młodzież szkolną w każdej wsi zagajników dla ptactwa:

Młodzież szkolna mogłaby również urządzić w każdej wsi zagajniki dla ptactwa, spożytkowując na ten cel naturalne zarośla głogów, tarniny, dzikich róż itp., albo zasadzić te krzewy z zebranych nasion na nieużytkach, na cmentarzach lub przy brzegach lasów. Zagajniki te mogłyby pozostawać pod waszą opieką, jako wasze „rezerwaty przyrodnicze” i przynosić poważną korzyść dla rolnictwa ${ }^{32}$.

Pomysłów na wykorzystanie darów ziemi było wiele. Dzikie rośliny nie były tylko ziołami o działaniu zdrowotnym, wykorzystywanymi w przemyśle spożywczym i codziennej kuchni. Było to również w trudnych czasach źródło skrobi, dlatego poszukiwano jej w podziemnych pędach trzcin, bulwach, liściach, owocach i nasionach roślin żyjących w warunkach dzikich i ogrodowych ${ }^{33}$. W cenie były też rośliny leśne, które dostarczały białka, tłuszczy, witamin, soli mineralnych i cukru. Uczono, jak je rozpoznawać, zbierać i jak dalej z nimi postępować.

Eksperymentom miczurinowskim nie było końca. I choć niepowodzeniami kończyły się próby aklimatyzacji upraw bawełny oraz szczepienia roślin zielonych (np. pomidora na ziemniaku) ${ }^{34}$, a pierwsza zjarowizowana ${ }^{35} \mathrm{w}$ trudzie pszenica nie nadawała się do wysiewu i zjadało ją ptactwo ${ }^{36}$, to odnosi się wrażenie, że nie efekty były tu naprawdę ważne, bo przecież działalność szkolnych kół nie była w stanie wpłynąć znacząco na wyniki gospodarki socjalistycznej, poprawić stanu drzewostanu czy podnieść wyników produkcji jedwabnika morwowego. Chodziło raczej o propagandę idei, podkreślane przez ówczesnych pedagogów wyrabianie hartu ducha oraz cierpliwości, a przede wszystkim - wywieranie wpływu wychowawczego i światopoglądowego. Czasami mówiono o prawdziwych sukcesach,

\footnotetext{
29 L. WIŚNIEWSKA, Hodujemy króliki, wyd. 3, Warszawa: Nasza Księgarnia 1964, s. 3.

${ }^{30}$ Z. BOHUSZEWICZ, Zbieramy nasiona drzew...

31 K. FRIEDEL, op. cit.

32 Z. BOHUSZEWICZ, Zbieramy nasiona drzew..., s. 12.

33 Z. BOHUSZEWICZ, Rośliny jadalne...

34 Nasze dziatki..., s. 26.

35 Jarowizowanie - poddawanie niskim temperaturom rozwijających się roślin.

36 Nasze dziatki..., s. 40-41.
} 
np. gdy z doświadczeń nad uprawą roślin oleistych mogła skorzystać miejscowa spółdzielnia produkcyjna ${ }^{37}$.

Kształtowaniu poglądów światopoglądowych służyły też wtręty historyczno-polityczne, zaprawione nadmiernym patetyzmem. Pojawiały się one czasami w najmniej oczekiwanych momentach, np. wśród wielu zastosowań jedwabiu podawano następujący:

Była pamiętna zima roku 1941. Wojska hitlerowskie podchodziły pod Moskwę. Śmiertelnie znużony żołnierz radziecki dobywał w walce ostatnich sił. Towarzysz Stalin rozkazał trwać, więc, wierząc, trwali. Wprawne ręce artylerzystów kładły w lufy dział pocisk za pociskiem i siały śmierć wśród wroga. Rozgrzane armaty trzeba było chłodzić mokrymi szmatami. Amunicyjni bez przerwy zbroili nowe pociski. Szykowali coraz to nowe ładunki, wkładając do łusek, zgodnie z rozkazem, 1-2-3 woreczki prochu. I tu też najlepsze są woreczki jedwabne. Jedwab wspomagał w walce o wolność i demokrację. Tak było aż do bram Berlina ${ }^{38}$.

Dzieci — bohaterowie tych książek — z radością myślały o zmianach, jakie zaszły w Polsce Ludowej, doceniały pomoc i „opiekę” Związku Radzieckiego i w przyszłości oczywiście widziały siebie jako budowniczych socjalizmu (sic!). To, co mogły zrobić w tamtej chwili, to dorzucić swoją małą, lecz ważną cegiełkę do wykonania planu gospodarczego, a przede wszystkim przyczynić się zwiększenia ilości surowca, zwłaszcza produktów żywnościowych, w kraju. Dlatego angażowane były przez nauczycieli do pracy w kołach, w szkołach odbywały się, traktowane $\mathrm{z}$ wielką powagą i zadęciem, posiedzenia badawcze i narady produkcyjne, czczono święto pierwszomajowe wylęgiem jedwabików i wieszano gazetki ścienne, pokazując wzrost produkcji w ZSRR ${ }^{39}$. Przy tych okazjach dzieci podejmowały i wykonywały zobowiązania pierwszomajowe (np. ukwiecenie szkoły ${ }^{40}$ ). Na ważniejszych imprezach szkolnych i zakończeniu roku szkolnego przemawiali, chwaląc te inicjatywy, delegaci partii, przedstawiciele władz, delegaci współpracujących ze szkołami instytucji.

W realizację programu kółek miczurinowskich angażowały się nie tylko władze oświatowe, lecz także państwowe gospodarstwa rolne i zakłady pracy. Zobowiązania, m.in. dotyczące zadań sadowniczych, a nawiązujące do tych, które masowo podejmowały w całym kraju drużyny harcerskie, były wraz z apelami o naśladownictwo publikowane w prasie dziecięcej i młodzieżowej. Bodźcem do ich inicjowania były przeróżne bieżące wydarzenia polityczne oraz realizacja obowiązujących doktryn, które, wraz programami nauczania przenikały do szkoły, a ich realizacja była skrzętnie sprawdzana. Przykładem może być początek książki

37 Ibidem, s. 113.

38 K. FRIEDEL, op. cit., s. 5.

39 W książce K. FRIEDELA pt. Gleba w naszym ... autor ponad jedną stroną przeznaczył na szczegółowy opis najpierw upadku, spowodowanego rewolucją, a potem wzrostu produkcji jedwabników w Kraju Rad i potem w ZSRR (s. 56-57).

40 Z. i I. WILSKIE, op. cit., s. 12-13. 
Tadeusza Pęczalskiego pt. Zakładamy szkolny sad (1956), w której autor przywołał zobowiązanie drużyny harcerskiej z Bożnowa (pow. Żagań) o nasadzeniach drzew owocowych dla uczczenia II Zjazdu Partii. Kończyło się ono patetycznym apelem: „Wzywamy wszystkich harcerzy z całej Polski do sadzenia drzew i krzewów owocowych w swojej wsi. Ukwiecimy sadami ojczystą ziemię!"41. Zakładano więc szkolne sady i obsadzano drogi drzewami owocowymi, sadzono nie tylko tam, gdzie było potrzeba i tyle ile trzeba, lecz na zapas, na wszelki wypadek, bo nigdy nie wiadomo było kiedy np. przyjdzie mroźna zima lub susza i przetrzebi naturalne zasoby. Umiejętności młodych sadowników miały być wspierane przez opiekuna koła (nauczyciela biologii, opiekuna klasy, przewodnika drużyny harcerskiej, członka komitetu rodzicielskiego) oraz właścicieli sadów: kierowników państwowych gospodarstw rolnych, zakładów sadowniczych, zarządów spółdzielni produkcyjnych, sadowników indywidualnych. Zalecano - w razie potrzeby — nawet kontakt z zarządem rolnictwa najbliższej powiatowej lub wojewódzkiej rady narodowej, który miał dopomóc w wyborze odpowiedniego miejsca wycieczki. Efektem miało być założenie szkolnego koła młodych sadowników ${ }^{42}$. Opieka powyższych instytucji miała być też przydatna przy szukaniu odpowiedniego gruntu pod sad czy działkę, jeśli szkoła nie dysponowała odpowiednim terenem, a także pozyskiwania sadzonek, które mogły być nieco tańsze niż w handlu. Zalecano wykorzystywanie do tego celu różnych okazji, np. V Festiwalu Młodzieży i Studentów. Chodziło też o nawiązywanie kontaktów z młodzieżą innych krajów, wymianę doświadczeń, zwłaszcza poprzez regularną korespondencję $e^{43}$.

Praca młodych bohaterów miała też być oznaką ich awansu społecznego. Bohaterka jednej z opowieści, czternastoletnia Jasia, córka dawnego fornala Grzelaka, skończyła po szkole podstawowej kursy hodowlane i była praktykantką w PGR Makowo. Sprzątała kurniki, pracowała wzorowo, z dużym zaangażowaniem, a przy tym bardzo lubiła zwierzęta, więc wiadomo już było, że w przyszłości będzie kierowniczką fermy drobiarskiej. Praca na fermie dostarczała jej wiele satysfakcji, wciąż czegoś nowego się uczyła, stale się dokształcała, czytając podręczniki ,z biblioteczki”. W toku narracji spotykamy przemyślenia młodej pracownicy fermy:

Od dwóch tygodni dajemy kurom skiełkowany owies — myślała praktykantka Jasia — Pobudza czynności rozrodcze. Słońce, ruch na powietrzu, białkowowitaminowa pasza, odpowiednia ilość kogutów — to wszystko wpływa na dobre zapłodnienie jaj. Ciekawam, jak wypadł pierwszy wyląg. Muszę zajrzeć do biblioteczki, sprawdzić, jak jest z tym rozmnażaniem kur. Wieczorem, w jasnej i ciepłej świetlicy praktykantka Jasia kończyła rozdział o czynnościach narządów rozrodczych kury... 44

\footnotetext{
41 T. PĘCZALSKI, op. cit., s. 3.

42 Ibidem, s. 7-8.

43 Ibidem, s. 81-82.

${ }^{44}$ L. WIŚNIEWSKA, op. cit., s. 3.
} 
Prowadziła ona też z sobą długie monologi, które służą w książce przede wszystkim uprzystępnieniu treści i ukazaniu rozwoju duchowego bohaterki, jej dojrzewania. Jej koleżanka Zocha, także i tu, na fermie, była przejęta wypracowaniem odpowiedniej normy: „Procent wylęgu będzie bardzo dobry. Może 70\%, pobije inne wylęgarnie - cieszyła się Zocha" 45 . Wzorem była oczywiście hodowla kołchozowa i sowchozowa w ZSRR, która dzięki doskonałej organizacji pracy przynosiła najlepsze wyniki, w tekście przywołuje się nawet konkretne dane produkcyjne ${ }^{46}$.

\section{PODSUMOWANIE}

Kółka biologiczne, koła młodych miczurinowców, kluby młodych agronomów i sadowników na pewno przyczyniały się do szerzenia wiedzy biologicznej i związanej z ochroną środowiska. Przy okazji jednak sączyły się z ich programów i publikacji wykorzystywanych w ich działalności idee rządzącego systemu. $\mathrm{Na}$ szczęście BMM jest jednym z niewielu przykładów książek popularnonaukowych o tematyce przyrodniczej, w których tak wyraźnie wciągano młodzież szkolną w założenia i realizację planów władzy. Sąsiednie państwa bloku socjalistycznego miały podobne publikacje. W książce pt. Gleba w naszym ogródku Karla Friedela (było to tłumaczenie z niemieckiego) przewodniczący kółka biologicznego i zarazem nauczyciel stawia naukę radziecką ponad imperialistyczne teorie ekonomiczne głoszące, że wzrost zaludnienia musi przynieść głód i nędzę. Przeciwstawieniem miała być właśnie teoria Miczurina, która przynosiła zbawienną teorię wydzierania przyrodzie jej bogactw, jeśli tylko pozna się dobrze naukowe prawa rządzące przyrodą ${ }^{47}$. Jej ideę propagowały też inne serie i książki poza seriami $^{48}$, a także specjalne publikacje metodyczne skierowane do nauczycieli ${ }^{49}$.

Również gdy książki nie zawierały zbyt wielu wtrętów ideologicznych, czuć w nich było ducha czasu, bo nawet tania i dostępna do wykorzystania jako ogrodzenie działki dzika róża mogła mieć dla autora znaczenie symboliczne — „jej

45 Ibidem, s. 11.

46 Ibidem, s. 26.

47 K. FRIEDEL, op. cit., s. 8-9.

48 Np. w serii „Biblioteka Harcerza” wydawanej przez Naszą Księgarnię: Zofia WILSKA, Ogródek na działce, Warszawa 1951; Nikolaj IVANČENKO, Nasza szkoła sadzi drzewa, Warszawa 1951.

49 Np. wydawane przez Państwowe Zakłady Wydawnictw Szkolnych (PZWS): Andrzej DREWNIAK, Doświadczenia na działce szkolnej, Warszawa 1954; Szczepan Aleksander PIENIĄŻEK (et al.), Działka szkolna młodych miczurinowców, Warszawa 1951; Zofia ROŚCISZEWSKA-GĄSIOROWSKA, Przekształcamy rośliny: doświadczenia i zadania, Warszawa 1951; Romuald ŻBIKOWSKI, Praca na szkolnej działce doświadczalnej, Warszawa 1954 i 1955. 
piękny kwiat wyrasta wśród kolców, podobnie jak dostatni plon na działce rośnie z trudu i wytrwałej pracy" ${ }^{50}$. Niektóre z tomików tej serii przetrwały czasy stalinizmu i były jeszcze później wydawane przez Naszą Księgarnię, już bez sygnowania serii, jako kolejne wydanie, np. Lucyny Wiśniewskiej Hodujemy króliki (wyd. 3, 1964).

Trudno dziś dotrzeć do informacji dotyczących środowiska autorów tych książek. Wiadomo, że przynajmniej część z nich to zapaleni popularyzatorzy wiedzy przyrodniczej, którzy musieli się dostosować do wymagań tamtego czasu. Mianowicie np. Zofia Bohuszewiczówna (1884-1953), pedagog, autorka podręczników szkolnych, została zapamiętana jako osoba, która już przed wojną pisała popularnonaukowe dziełka dla dzieci i współredagowała serie wydawnicze (np. „Biblioteczka Przyrodnicza”, „Ze Świata Przyrody”). W swojej pracy szkolnej była wielką orędowniczką zasady niepodawania gotowych wiadomości, zwłaszcza takich, do których odkrycia uczeń mógł dotrzeć sam, pod kierunkiem pedagoga. $\mathrm{Z}$ zaangażowaniem przybliżała też polskim czytelnikom książki przyrodnicze autorów francuskich i niemieckich, tłumacząc je na język polski. Po wojnie kontynuowała tę działalność, jej podręczniki i książki popularnonaukowe zawsze niosły dużą dawkę wiedzy, lecz nigdy nie charakteryzowały się jej nadmiarem. Jak wspomina po latach Jerzy Wysokiński:

Mimo że były one pisane w czasie silnej indoktrynacji, nie zawierają przeładowania ideologicznego, a tylko podstawowe, ,jedyne prawdy", wymagane przez władze (np. zawierają rozdziały, zatytułowane „Jak Polska Ludowa pomaga swoim obywatelom” lub „Jak prowadzi się walkę z jaglicą w Polsce Ludowej" lub takie pochwalne treści o nowym państwie, jak np. informacja, że w Strzelinie istnieją państwowe chłodnie i zamrażalnia owoców ${ }^{51}$.

Autorami byli też pracownicy naukowi, np. Jadwiga Wernerowa (1896-1980), która obroniła doktorat z zoologii, przed wojną i w latach 1948-1953 prowadziła koło zainteresowań przy ogrodzie zoologicznym w Warszawie. Nagrywała audycje oświatowe dla dzieci i młodzieży oraz pisała podręczniki szkolne i książki popularyzujące wiedzę przyrodniczą. Wiele jej książek zawiera niezwykle interesujące ciekawostki z życia zwierząt, a opowieści-gawędy (np. Rudzia, I wyd. 1958) mają ponadczasowe walory literackie, poznawcze i wychowawcze ${ }^{52}$.

Z podobnego środowiska wywodził się niestrudzony popularyzator wiedzy zoologicznej Jan Żabiński (1897-1974), który był zoologiem (doktorat i habilitacja), fizjologiem i hodowcą, organizatorem i wielololetnim dyrektorem warszaw-

50 Nasze dziatki..., s. 8 .

51 J. WYSOKIŃSKI, Zofia Bohuszewicz (1884-1953). Wspomnienie w 60. rocznicę śmierci, http://www.warszawa.pl/ramka/?l=Edukacja/129,9754,2,1,0,0-Zofia_Bohuszewicz_1884_\%E2\% 80\%93_1953.html [dostęp: 12 VII 2016].

${ }^{52}$ Wernerowa Jadwiga, [w:] Nowy stownik literatury dla dzieci i młodzieży, red. K. Kuliczkowska, B. Tylicka, Warszawa: Wiedza Powszechna 1984, s. 371. 
skiego ogrodu zoologicznego. Podobnie jak omówione autorki, on również jeszcze przed wojną rozpoczął działalność popularyzatorską, wygłaszając pogadanki przyrodnicze w Polskim Radiu. Po wojnie wydał kilkadziesiąt książek popularnonaukowych, w tym wiele dla młodych czytelników, a jego lekkie i dowcipne gawędy są już niemal klasyką tego gatunku (np. Jak powstała trąba słonia 1955, Z psychologii zwierząt 1956, Czy można żyć bez skóry 1958, Podobny do ojca czy dziadka 1959). Zajmował się także pracą naukową, co nie przeszkodziło mu poświęcać siły i czas na przygotowywanie kolejnych publikacji dla najmłodszych przyrodników $^{53}$. Dzięki tym i wielu innym niestrudzonym autorom dzieci i młodzież miały okazję poznać arkana świata nauki, a przede wszystkim otaczającego świata, w łatwy, przystępny sposób. Jak widać, nawet czasy stalinizmu nie przeszkodziły w przyjętym programie szerzenia wiedzy, a niewielka dawka indoktrynacji, jaką w ówczesnych książkach musieli zawrzeć autorzy i wydawcy, by mogły w ogóle zostać opublikowane, jest dziś świadectwem minionej epoki.

\section{Wykaz książek serii „Biblioteka Młodych Miczurinowców”} (wszystkie wydane w Warszawie przez Naszą Księgarnię):

Biegańska-Kornowska J., Leśna apteka, 1954.

Błażejewicz W., Życie chwastów, 1954.

Bohuszewicz Z., Rośliny jadalne dziko rosnace, 1955.

Bohuszewicz Z., Zbieramy nasiona drzew i krzewów, 1953 i 1955.

Friedel K., Gleba w naszym ogródku, 1955.

Herman W., Hodowla jedwabników w szkole, 1954.

Nasze działki szkolne, 1956.

Pęczalski T., Zakładamy szkolny sad, 1956.

Walles M.F., Akwarium i jego urzadzenie, 1954 i 1955.

Walles M.F., Drobne zwierzęta wodne w akwarium, 1954 i 1955.

Wernerowa J., Na goracym uczynku, 1955.

Wilskie Z. i I., Szkoła w kwiatach, 1955.

Wiśniewska L., Hodujemy króliki, 1953 i 1955.

Wiśniewska L., Od 12 do 312 jaj, 1953.

Żabiński J., Sami się przekonamy, 1954.

53 Jan Żabiński, [w:] Nowy słownik literatury..., s. 388. 
BOGUMIŁA STANIÓW

\section{BOOKS FROM THE "BIBLIOTEKA MŁODYCH MICZURINOWCÓW" SERIES AS AN EXAMPLE OF HOW POPULARISATION OF KNOWLEDGE WAS COMBINED WITH IDEOLOGISATION OF YOUNG PEOPLE IN THE 1950S}

\section{Summary}

In the article the author discusses the Biblioteka Młodych Miczurinowców (Young Michurinist Library) - a series of popular science books about nature for children and young people published in post-war Poland in 1953-1956. She explores the specificity of the books from the series, which - in addition to information about plants, animals and their amateur husbandry - also provided their readers with elements of the communist ideology. They were to disseminate the idea of Michurinism launched by the famous Soviet biologist and experimenter Ivan Michurin. School gardens and farms were used to teach pupils how to cultivate crops and use generally available plants to the maximum, and how to enrich their diet with farm animals that were easy to manage. The simple, largely fictionalised stories about nature, featuring a basic end matter, were to help teachers develop children's and young people's socialist worldview, and teach the contents recommended by the ministry.

KEY WORDS: popular science literature for children and young people, Young Michurinist Library, Poland, 1953-1956 